ISSN = 1980-993X - doi:10.4136/1980-993X
www.ambi-agua.net
E-mail: ambi-agua@agro.unitau.br
Tel.: (12) 3625-4212

\title{
Antimicrobial resistance profiles of diarrheagenic Escherichia coli strains isolated from bathing waters of the Lajeado reservoir in Tocantins, Brazil
}

(http://dx.doi.org/10.4136/ambi-agua.756)

\author{
Kleverson Wessel de Oliveira'; Fátima de Cássia Oliveira Gomes²; \\ Guilherme Benko'; Raphael Sanzio Pimenta'; Paula Prazeres Magalhães; \\ Edilberto Nogueira Mendes ${ }^{3}$; Paula Benevides de Morais ${ }^{1,4}$ \\ ${ }^{1}$ Laboratório de Microbiologia Ambiental e Biotecnologia, Universidade Federal do Tocantins, Palmas - TO, \\ ${ }^{2}$ Centro Federal de Educação Tecnológica de Minas Gerais CEFET-MG, \\ ${ }^{3}$ Universidade Federal de Minas Gerais-UFMG, \\ emails: oliwessil@uft.edu.br, fatimaog@dppg.cefetmg.br, benko@uft.edu.br, pimentars@uft.edu.br, \\ ppmagalhaes@icb.ufmg.br, enmendes@medicina.ufmg.br, moraispb@uft.edu.br
}

\begin{abstract}
The exposure to contaminated water constitutes an important mechanism for the transmission of gastrointestinal pathogens. Diarrheagenic Escherichia coli strains cause enteric infections in humans and include six different categories according to virulence factors. This paper aims at detecting the presence of diarrheagenic E. coli strains in bathing waters of seven beaches of Lajeado Reservoir, in the Tocantins River in Brazil, and to test the resistance to antimicrobial drugs to correlate with possible contamination of the water with human feces. Total coliform and E. coli counts were done by the Colilert ${ }^{\mathrm{TM}}$ chromogenic substrate technique. Biochemical identification was accomplished by API20E and detection of virulence factors by PCR, employing specific primers for Shiga, LT, and ST and intimin genes. The susceptibility to 16 antibiotics was tested by disk-diffusion technique. Among one hundred and forty-nine strains of E. coli, two strains of EPEC and two of ETEC were detected in waters of beaches situated in urban areas, close to sewage discharge. These strains presented resistance to three to six antibiotics. Human origin is suggested based on the multiresistant profile of these strains.
\end{abstract}

Keywords: Diarrheagenic Escherichia coli, antimicrobial resistance, virulence factors, PCR and river beach waters.

\section{Perfis de resistência antimicrobiana de cepas de Escherichia coli diarreiogênicas isoladas de praias do Reservatório de Lajeado, em Tocantins, Brasil}

\section{RESUMO}

A exposição humana à água contaminada constitui um importante mecanismo para a transmissão de patógenos gastrointestinais. Cepas de Escherichia coli diarreiogênicas podem causar infecções entéricas em humanos e incluem seis categorias diferentes de acordo com fatores de virulência. Este trabalho tem por objetivos detectar a presença de cepas diarreiogênicas de E. coli nas águas de sete praias do reservatório de Lajeado, Tocantins, Brasil e testar a resistência a drogas antimicrobianas para correlacionar com a possível contaminação da água por fezes humanas. As contagens de coliformes totais e E. coli foram realizadas pela técnica do substrato cromogênico Colilert ${ }^{\mathrm{TM}}$. A identificação bioquímica foi realizada utilizando kit API20E e a detecção dos fatores de virulência por PCR, empregando 
primers específicos para Shiga, LT e ST e genes de intimina. A susceptibilidade a 16 antibióticos foi testada pela técnica de difusão em discos de papel impregnados com antibiótico. Entre as 149 cepas de E. coli testadas, duas cepas de EPEC e duas de ETEC foram detectadas em águas de praias situadas em áreas urbanas, perto de descarga de efluentes. Estas cepas apresentaram resistência de 3 a 6 antibióticos. A provável origem humana das cepas é sugerida devido ao perfil de multiresistentes apresentado.

Palavras-chave: Escherichia coli diarreiogênicas, resistência a antimicrobianos, fatores de virulência, PCR e praias fluviais.

\section{INTRODUCTION}

The presence of E. coli in food and water constitutes a major health concern. The dissemination of these bacteria in the aquatic environment may derive from the contact with human and animal excreta, and they may accumulate in the aquatic sediment (Haller et al., 2009). Epidemiological studies have depicted that high densities of E. coli in recreational waters is related to gastroenteritis in humans (Alm et al., 2006). Many E. coli strains are commensal; however there are strains that display the ability to cause enteric infections in mankind, named diarrheagenic E. coli (DEC), a group which includes emerging pathogens of public health importance (Vidal et al., 2005). The worldwide contamination of surface and potable waters by diarrheagenic $E$. coli due to addition of untreated sewerage has been demonstrated (Hamner et al., 2007; Higgins et al., 2005). DEC are described under six categories or pathotypes according to virulence factors: Enteropathogenic E. coli (EPEC), Enterotoxigenic E. coli (ETEC), Enterohemorrhagic E. coli (EHEC), Enteroinvasive E. coli (EIEC), Enteroaggregative E. coli (EAEC) and Diffusely adherent E. coli (DAEC) (Huang et al., 2006). The transmission of virulence factors among strains may contribute toward their pathogenicity and increases their diversity in the environment (Obi et al., 2004).

The Lajeado Reservoir was formed by the construction of the Luis Eduardo Magalhães Hydroelectric Dam in the Tocantins River and seven municipalities are situated in its area of influence, discharging effluents from sewage treatment plants (two municipalities, Palmas and Porto Nacional) or raw sewage (five municipalities), combined with intense land use for cattle raising of the surrounding area. The reservoir also displays bathing areas (beaches) that were created by the municipalities of Porto Nacional and Palmas cities or by the communities themselves. These beaches are considered touristic attractions being heavily used by bathers, increasing anthropic pressure on this resource especially during the dry season, from June to September annually.

This work aims to detect the occurrence of DEC strains in the waters of the main beaches of Lajeado Reservoir in order to discuss the possible human source of bacterial contamination in the reservoir waters and to describe their profile of antimicrobial drug resistance.

\section{MATERIALS AND METHODS}

\subsection{Characterization of the beaches}

The Lajeado Reservoir has a total area of $620 \mathrm{~km}^{2}$ and an extension of $172 \mathrm{~km}$ in Mid Tocantins River, between the municipalities of Lajeado and Ipueiras, in the State of Tocantins, Brazil, receiving direct influence from the municipalities of Brejinho de Nazaré, Ipueiras, Porto Nacional, Palmas, Lajeado, Miracema and Tocantínia, which constitute a total of 220.147 inhabitants. Permanent beaches have been built in the right margin of this reservoir in contrast to the seasonal river beaches typical of the Central-North region of Brazil 
that are created during the dry season and vanish under the river waters during annual floods from December to April. Among these six permanent beaches, five are located in urban centers ARNO, Prata and Graciosa beaches in Palmas, capital of Tocantins, and Porto Real beach in Porto Nacional city. The Caju and Buriti beaches in Palmas are distant from the urban centers, in rural areas occupied by cattle raising.

\subsection{Isolation and biochemical identification of Escherichia coli strains}

A total of sixty water samples, ten for each one of the six beaches of the reservoir were collected, being five samples between June and August, 2008 (dry season) and five between November 2008 and February 2009 (rainy season). The water samples were taken to the laboratory within two hours after collection, aseptically inoculated into Colilert ${ }^{\mathrm{TM}}$ (IDEXX ${ }^{\mathrm{TM}}$ ) QuantiTray of 98 wells, and incubated for $18 \mathrm{~h}$ at $35^{\circ} \mathrm{C}$, for determination of total coliforms and $E$. coli counts. The wells presenting typical fluorogenic reaction (E. coli presence) were inoculated using a bacteriological loop on Petri dishes containing Eosin Methylene Blue (EMB) Agar (Oxoid ${ }^{\mathrm{TM}}$ ), and then incubated at $37^{\circ} \mathrm{C}$ for 24 to $48 \mathrm{~h}$. Up to five typical $E$ coli colonies from each water sample were recovered from EMB plates, and all colonies were submitted to Gram staining and inoculated in $2 \mathrm{~mL}$ of Brain Heart Infusion (BHI) broth (Acumedia ${ }^{\mathrm{TM}}$ ) and incubated at $37^{\circ} \mathrm{C}$ for $24 \mathrm{~h}$ after which they were dispensed into cryogenic vials supplemented by $20 \%$ glycerol and placed at $-80^{\circ} \mathrm{C}$ freezer for further identification. Biochemical tests were performed by using API 20E strips (bioMerieux ${ }^{\mathrm{TM}}$ ).

\subsection{Detection of diarrheagenic Escherichia coli}

DNA was extracted from all strains identified as E. coli by a phenol-chloroform method. All PCR mixtures were cycled in an Eppendorf thermocycler. The following genetic virulence markers were investigated by employing specific primers previously described: eae (Reid et al., 1999), bfpA (Gunzburg et al., 1995), stxl (Vidal et al., 2004), stx2 (Vidal et al., 2004), elt (Aranda et al., 2004), and est (Aranda et al., 2004). PCR mixtures had final volumes of $20 \mu \mathrm{L}$ consisting of reaction buffer (Tris $\mathrm{HCl} 10 \mathrm{mM}-\mathrm{pH} 8.4, \mathrm{KCl} 25 \mathrm{mM}$ ), 1.0 to $1.5 \mathrm{mM} \mathrm{MgCl}_{2}$, $200 \mu \mathrm{M}$ each dNTP (Promega ${ }^{\mathrm{TM}}$ ), $0.5 \mu \mathrm{M}$ each primer (Integrated DNA Technologies), $1 \mathrm{U}$ Taq DNA polymerase (Phoneutria ${ }^{\mathrm{TM}}$ ), and $20 \mathrm{ng}$ DNA. Primers and thermocycling conditions are shown in Table 1. Amplicons were discriminated in $8 \%$ polyacrylamide gels $\left(\right.$ Sigma $\left.^{\mathrm{TM}}\right)$, stained with ethidium bromide $\left(\right.$ Sigma $\left.^{\mathrm{TM}}\right)$, visualized under UV light (Cole-Parmer), and compared to a standard of $100 \mathrm{bp}\left(\right.$ Fermentas $\left.^{\mathrm{TM}}\right)$. Positive controls for eae, stxl, and stx2 (E. coli CDC EDL-933, INCQS 00171), bfpA (E. coli CDC O126, INCQS 000184), elt (E. coli 0761-2), and est (E. coli 0122-4), negative control (E coli ATCC 25922), and negative internal control (sterile Milli- $\mathrm{Q}^{\circledR}$ water; Millipore ${ }^{\mathrm{TM}}$ ) were included in each batch of reaction.

\subsection{Antimicrobial susceptibility test}

The investigation of antimicrobial susceptibility was carried out by the Kirby-Bauer disk diffusion method using the standard concentrations of ampicillin, amoxicillin + clavulanate, cefoxitin, gentamicin, amikacin, cefepime, cephalothin, cefuroxime, ceftriaxone, ceftazidime, ciprofloxacin, sulfamethoxazole+trimethoprim, cefotaxime, tetracycline, chloramphenicol, tobramycin and ticarcilin+ clavulanate (CLSI, 2009).

\subsection{Statistical analysis}

Geometric means of the counts of $E$. coli during dry and rainy seasons and among the six beaches were compared using $t$ test. Significant value was set to $\mathrm{p}<0.05$. 
OLIVEIRA, K.W.; GOMES, F. C. O.; BENKO, G.; PIMENTA, R. S.; MAGALHÃES, P.P.; MENDES, E. N.; MORAIS, P. B. Antimicrobial resistance profiles of diarrheagenic Escherichia coli strains isolated from bathing waters of the Lajeado reservoir in Tocantins, Brazil. Ambi-Agua, Taubaté, v. 7, n. 2, p. 30-41, 2012. (http://dx.doi.org/10.4136/ambi-agua.756)

Table 1. PCR conditions employed for EPEC, EHEC, and ETEC identification.

\begin{tabular}{|c|c|c|c|c|}
\hline Gene & Primer & $\begin{array}{c}{\left[\mathrm{MgCl}_{2}\right]} \\
\mathbf{m M}\end{array}$ & Program & $\begin{array}{c}\text { Amplicon } \\
\text { (bp) }\end{array}$ \\
\hline Eae & $\begin{array}{l}\text { F:5' CTG AAC GGC GAT TAC } \\
\text { GCG AA 3' } \\
\text { R: 5' CCA GAC GAT ACG ATC } \\
\text { CAG 3' }\end{array}$ & 1.0 & $\begin{array}{l}95^{\circ} \mathrm{C} / 40 \mathrm{~s}, 53^{\circ} \mathrm{C} / 2 \mathrm{~min}, 60^{\circ} / 2 \\
\min -40 \mathrm{x}\end{array}$ & 917 \\
\hline$B f p A$ & $\begin{array}{l}\text { F:5' AAT GGT GCT TGC GCT } \\
\text { TGC TGC 3' } \\
\text { R:5' GCC GCT TTA TCC AAC } \\
\text { CTG GTA 3' }\end{array}$ & 1.0 & $\begin{array}{l}95^{\circ} \mathrm{C} / 40 \mathrm{~s}, 53^{\circ} \mathrm{C} / 2 \mathrm{~min}, 60^{\circ} \mathrm{C} / 2 \\
\min -40 \mathrm{x}\end{array}$ & 326 \\
\hline stxl & $\begin{array}{l}\text { F:5' CAG TTA ATG TGG TGG } \\
\text { GGA AGG 3' } \\
\text { R:5' CCA CAG ACA ATG TAA } \\
\text { CCG CTG 3' }\end{array}$ & 1.0 & $\begin{array}{l}95^{\circ} \mathrm{C} / 20 \mathrm{~s}, 61^{\circ} \mathrm{C} / 40 \mathrm{~s}, \\
72^{\circ} \mathrm{C} / 90 \mathrm{~s}-30 \mathrm{x}\end{array}$ & 348 \\
\hline stx 2 & $\begin{array}{l}\text { F:5' ATC CTA TTC CCG GGA } \\
\text { GTT TACG 3' } \\
\text { R:5' GCG TCA TCG TAT ACA } \\
\text { CAG GACC 3' }\end{array}$ & 1.5 & $\begin{array}{l}95^{\circ} \mathrm{C} / 20 \mathrm{~s}, 61^{\circ} \mathrm{C} / 40 \mathrm{~s}, \\
72^{\circ} \mathrm{C} / 90 \mathrm{~s},-30 \mathrm{x}\end{array}$ & 584 \\
\hline Elt & $\begin{array}{l}\text { F:5' GGC GAG AGA TTA TAC } \\
\text { CGT GC 3' } \\
\text { R:5' CGG TCT CTA TAT TCC } \\
\text { CCT GTT 3' }\end{array}$ & 1.2 & $\begin{array}{l}95^{\circ} \mathrm{C} / 5 \mathrm{~min} ; 95^{\circ} \mathrm{C} / 45 \mathrm{~s}, \\
50^{\circ} \mathrm{C} / 1 \mathrm{~min}, 72^{\circ} \mathrm{C} / 1 \mathrm{~min}- \\
40 \mathrm{x} ; 72^{\circ} \mathrm{C} / 7 \mathrm{~min}\end{array}$ & 450 \\
\hline Est & $\begin{array}{l}\text { F:5' AAA GGA GAG CTT CGT } \\
\text { CAC ATT TT 3' } \\
\text { R:5' AAT GTC CGT CCT GCT } \\
\text { TTA GGA C 3' }\end{array}$ & 1.2 & $\begin{array}{l}95^{\circ} \mathrm{C} / 5 \min ; 95^{\circ} \mathrm{C} / 45 \mathrm{~s}, \\
50^{\circ} \mathrm{C} / 1 \mathrm{~min}, 72^{\circ} \mathrm{C} / 1 \mathrm{~min}- \\
40 \mathrm{x} ; 72^{\circ} \mathrm{C} / 7 \mathrm{~min}\end{array}$ & 190 \\
\hline
\end{tabular}

\section{RESULTS AND DISCUSSION}

All water samples were positive for the presence of $E$. coli both in the dry and rainy seasons (Figure 1). During the dry season, the highest counts of E. coli indicating high levels of fecal contamination were obtained at ARNO (133.2 Most Probable Numbers MPN/100mL), Prata (95.8 MPN/100mL) and Caju (93.5 MPN/100mL) beaches. In Porto Real beach, the counts were $5.6 \mathrm{MPN} / 100 \mathrm{~mL}$, the lowest during the dry season. In the rainy season Caju Beach presented the lowest values of of E. coli counts $(6.4 \mathrm{MNP} / 100 \mathrm{~mL})$. In Buriti and Porto Real beaches counts were lower in the dry season than in the rainy season, a different pattern to that found at other beaches. When E. coli counts detected in samples collected from each beach in dry and rainy seasons were compared using variance analysis significant difference was observed only for Caju Beach $(\mathrm{p}=0.0152)$. Similarly the analysis showed differences among beaches in the same season (Figure 2). In the dry season Porto Real and Buriti beaches showed similar low E. coli counts whereas in Caju, Prata and ARNO Beaches similar high counts were observed. Also in the rainy season similar low E. coli counts were found in Porto Real and Buriti beaches and high counts in Prata and ARNO. 
OLIVEIRA, K.W.; GOMES, F. C. O.; BENKO, G.; PIMENTA, R. S.; MAGALHÃES, P.P.; MENDES, E. N.; MORAIS, P. B. Antimicrobial resistance profiles of diarrheagenic Escherichia coli strains isolated from bathing waters of the Lajeado reservoir in Tocantins, Brazil. Ambi-Agua, Taubaté, v. 7, n. 2, p. 30-41, 2012. (http://dx.doi.org/10.4136/ambi-agua.756)

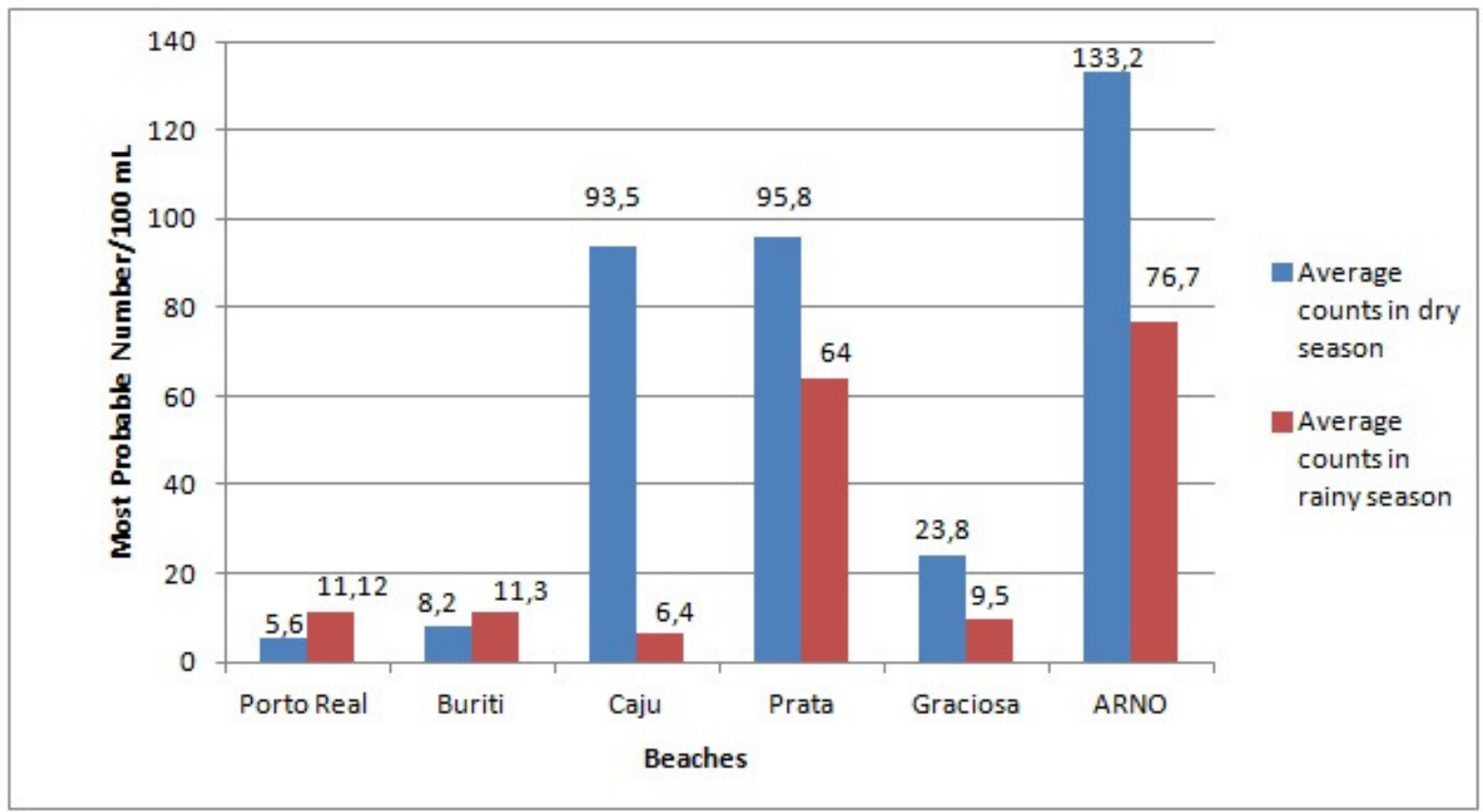

Figure 1. Variance analysis of the geometric media of $E$. coli counts in water samples from six beaches in the Lajeado Reservoir comparing data from the dry and rainy seasons of 2008/2009. Columns marked with the same letter are significantly similar according to $\mathrm{T}$ test with $5 \%$ of significance.
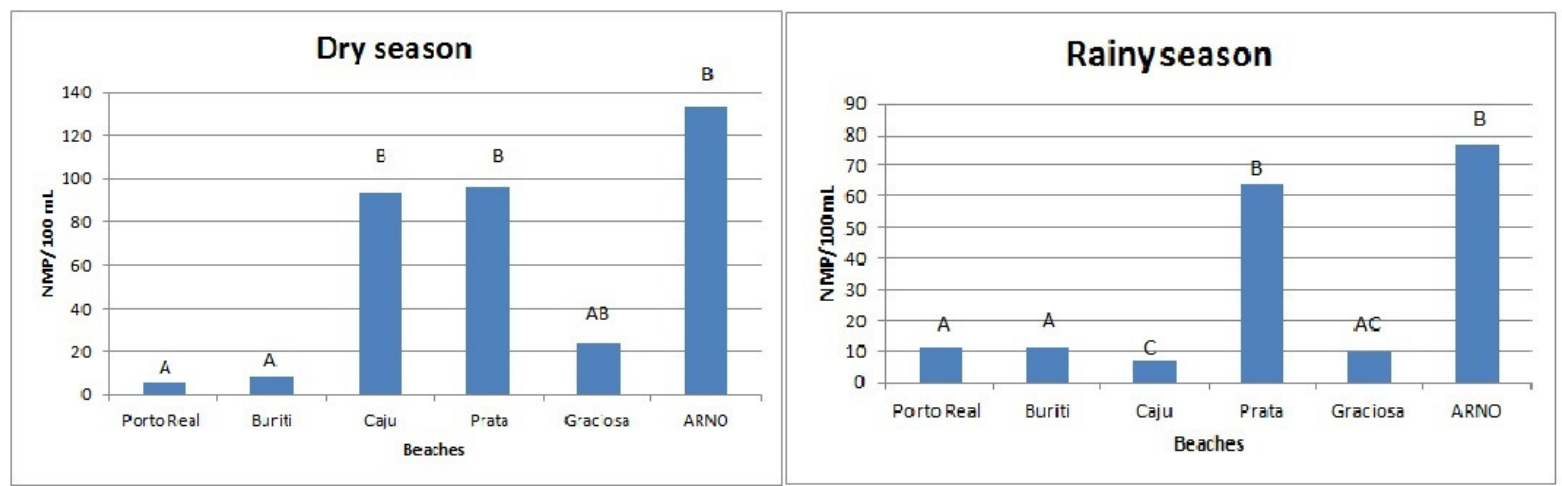

Figure 2. Variance analysis of the geometric media of $E$. coli counts in water samples from the Lajeado Reservoir comparing data from six different beaches in the dry (2.1) and rainy (2.2) seasons of 2008/2009. Columns marked with the same letter are significantly similar according to $t$ test with $5 \%$ of significance.

The investigation of water samples positive for E. coli in Colilert tests resulted in the isolation of 163 strains with typical E. coli lact profile from which $149(91.1 \%)$ were confirmed by the API20E (BioMerieux ${ }^{\mathrm{TM}}$ ). Among the other $8.9 \%$, seven were identified as Enterobacter cloacae, two as Citrobacter spp., two as Enterobacter intermedium and one each of Klebsiella pneumoniae, Serratia spp. and Escherichia vulneris.

Four out of the 149 E. coli strains were identified by PCR as DEC, two atypical EPEC $(e a e+, s t x-$ and $b f p-)$ and two ETEC (elt positive) isolates. All of them were isolated from water samples of beaches located in urban areas: EPEC strains were recovered from one water sample obtained at Porto Real beach in Porto Nacional and ETEC strains were obtained from samples collected in ARNO beach in Palmas, in the dry season. 
EPEC isolates presented two multiresistance profiles, one strain resistant to sulfamethoxazole + trimethoprim, tetracycline, and cephalothin and the other strain resistant to sulfamethoxazole +trimethoprim, tetracycline, ampicillin, and chloramphenicol. In regard to ETEC one isolate was resistant to tetracycline and ampicillin and the other to sulfamethoxazole + trimethoprim, tetracycline, amoxicillin + clavulanate, ticarcillin +clavulanate, ampicillin and cephalothin.

According to Colilert testing, all the beaches fall in the category "Excellent for bathing" according to Brazilian regulations (Brasil, 2000), although DEC were isolated. Accidental water ingestion from the Lajeado Reservoir during bathing may constitute risks for human health, especially children. There was no significant difference in the E. coli counts between dry and rainy seasons, except for Caju Beach as shown in Figure 1. Porto Real, Buriti and Graciosa beaches presented low counts during both periods, and ARNO and Prata beaches presented high counts during both periods. This is probably due to the higher numbers of bathers that go to these latter two beaches, the most popular of Palmas, during the whole year. The Caju beach presented higher counts in the dry than in the rainy season, probably due to the higher frequency of bathers during the dry months of June to August.

The isolation of strains that belong to other enterobacterial species in Colilert wells is likely due to the simultaneous detection of both total coliforms and E. coli by this method. Besides E. coli, the total coliform group includes Citrobacter, Enterobacter, Klebsiella, Serratia and other species of Escherichia that may be found in feces and also in the environment (APHA et al., 2005). Several studies have shown that Colilert systems produce false positive results in the detection of coliform bacteria and also E. coli (e.g. Pisciotta et al., 2002). In a study of drinking water reservoirs, Kämpfer et al. (2008) identified $95 \%$ of bacterial isolates from Colilert-18 positive samples as coliforms of fecal origin, but some isolates were identified by the API 20E system as Enterobacter species of the Enterobacter cloacae complex, Serratia spp., Citrobacter spp. and Klebsiella spp. A more detailed identification resulted in the identification of Enterobacter nimipressuralis, E. amnigenus, E. asburiae, E. hormaechei, and Serratia fonticola as predominant coliforms. These species are often not of fecal origin and may interfere with the ability to accurately detect coliforms of fecal origin. Chao et al. (2004) isolated pure cultures from 240 yellow wells in Colilert-18 tests and 16 isolates out of 23 non-coliform bacteria were Erwinia carotovora. They showed that the false-positive rate for coliform detection was about $9.6 \%$.

ETEC strains were detected in samples from ARNO beach and may be originated from sewage effluents that arrive in the reservoir from the Água Fria sewage treatment plant in Palmas. ETEC is regarded as a major cause of $E$. coli mediated diarrhea worldwide in humans, affecting mainly children and travelers (Turner et al., 2006). In the developing world, an estimated 650 million cases of ETEC infections occur each year, resulting in $~ 800,000$ deaths, mostly in young children (WHO, 1999). A study of Singh et al. (2010) showed that aquatic vegetation and leafy vegetables cultivated in riverine systems could be important environmental reservoirs of ETEC in the Gangetic river system, in India. Other studies suggested that aquatic flora and leafy vegetables could serve as nonpoint sources of human bacterial pathogens (Bhanumathi et al., 2003; Brandl, 2008; Ishii et al., 2006). Nonetheless, there is no significant horticulture in the Lajeado Reservoir margins, and although aquatic macrophytes are common in the reservoir, they are absent from the beaches areas.

Two EPEC strains were found in a water sample from Porto Real beach and may have been introduced in the water by sewage directly disposed into the reservoir or through the São João stream, which receives sewage from Porto Nacional, an urban area of 46,722 inhabitants. EPEC are among the most important pathogens infecting children worldwide and are one of the main causes of persistent diarrhea in both developing and developed countries (Ochoa et 
al., 2008). A study of E. coli in water, sediment and plankton collected from two sampling sites in a freshwater lake extensively used by humans and animals in India showed that the lake is an important source of EPEC and other related DEC (Fei et al., 2003). Of the 150 strains which were characterized, $31(20.7 \%)$ were found to belong to the classic EPEC serogroups.

There are very few studies reporting DEC in waters in Brazil. Nascimento et al. (2007) reported the detection of five ETEC strains, three of them elt positive and two elt and est positive, in samples from sewerage of Porto Alegre, Brazil. Cardonha et al. (2004) detected two EPEC classical serogroups in Ponta Negra beach, Natal, near sewerage galleries. Sato et al. (1983) demonstrated the presence of ETEC in waters and sewage from São Paulo. Valentini et al. (1992) isolated EPEC, ETEC, and EIEC strains from recreational lakes, dams, mines, rivers, and wells, and from treated water (swimming pool) in São Paulo. Falcão et al. (1993) also isolated EPEC, ETEC and EIEC from fresh waters in Araraquara, Brazil.

Other studies detected enteropathogenic E. coli in water in different tropical (Begum et al., 2005; Bern et al., 1992; Qadri et al., 2005) and non-tropical regions (Bern et al., 1992; Obi et al., 2004). Obi et al. (2004) screened a total of 228 river samples in Africa, and recovered E. coli from $200(87.7 \%)$ and $135(67.5 \%)$ of water and sediment, respectively and genes coding for necrotoxigenic E. coli $(35.6 \%)$ and EPEC (34.1\%) were most frequently encountered. Hamelin et al. (2006) points to the potential public health threat of $E$. coli pathotypes originating from municipal wastewater sources. They showed a higher frequency $(48 \%)$ of $E$. coli isolates possessing virulence and antimicrobial resistance genes in an urban site located downstream of wastewater effluent outfalls than in other examined sites (average of 24\%), although they isolated mostly extraintestinal pathogenic E. coli, a few EAEC and some atypical EPEC.

The antimicrobial susceptibility profiles of DEC in Lajeado Reservoir waters indicated that both ETEC and EPEC isolates represent different strains since their multiresistant profiles were dissimilar. Multiple antibiotic resistance is common among EPEC (Donnenberg, 1995). Fei et al. (2003) showed that all clinical isolates of EPEC obtained from patients with diarrhea in a Malaysia hospital were resistant to furoxime, cephalothin and sulphamethoxazole. They argue that the high incidence of antibiotic-resistant isolates of EPEC may be due to the widespread use of antibiotics.

Recently, multiple antibiotic resistance for kanamycin, nalidixic acid, tetracycline and trimethoprim have been shown in fecal coliforms isolated from both stool samples from humans and treated drinking water in India (Pathak and Gopal, 2008). Similarly, high resistance levels to ampicillin, trimethoprim/sulfamethoxazole, gentamicin and tetracycline have been detected in E. coli isolates from drinking water sources in Jordan (Shehabi et al., 2006). Ozgumus et al. (2007) found that antibiotic-resistant coliforms were widespread in water samples from ten rivers in Northern Turkey.

It has been reported that in natural environments, resistant organisms can be indigenous or introduced by natural or anthropogenic causes (Hu et al., 2008). Numerous factors might be involved for the release of resistant strains in the environment. Insufficient sanitation facilities, indiscriminate use of antibiotics and lack of well-managed sewerage systems are important contributing factors (Ozgumus et al., 2008). Although there is no data available on the performance of sewerage treatment plants in the urban margins of Lajeado Reservoir, it is largely known that solely two of seven municipalities present collection and treatment of sewage in the area. 


\section{CONCLUSIONS}

Although coliform and E. coli counts in water samples collected from the Lajeado Reservoir did not exceed the standards for safety of bathers according to legal regulations, the presence of DEC strains in these waters may still represent a risk that would be neglected by standard water quality evaluation methods.

According to Singh et al. (2010) despite the potential public health threat from waterand foodborne ETEC, regulatory authorities in the developing world rely exclusively on "indicators" of fecal pollution (e.g., fecal coliform bacteria or generic E. coli) for determination of water quality. This fails to provide a clue on presence of pathogenic forms of E. coli viz., ETEC present in the contaminated source. Since detection of DEC is not part of the routine monitoring of fecal contamination in reservoir waters this study contributes to better knowledge of the occurrence of pathogenic E. coli in the Lajeado Reservoir and ultimately to help designing strategies for improving standards of freshwater safety in Brazil.

\section{ACKNOWLEDGEMENTS}

ETEC strains were kindly given by Dr. Tânia Aparecida Tardelli Gomes do Amaral, UNIFESP, Brazil. This research was sponsored by CT-Hidro/ CNPq Processo 5526902005-8.

\section{REFERENCES}

ALM, E. W.; BURKE, J.; HAGAN, E. Persistence and potential growth of the fecal indicator bacteria, Escherichia coli, in Shoreline Sand at Lake Huron. Journal of Great Lakes Research, Ann Arbor, v. 32, p. 401-405, 2006. http://dx.doi.org/10.3394/03801330(2006)32[401:PAPGOT]2.0.CO;2

AMERICAN PUBLIC HEALTH ASSOCIATION - APHA; AMERICAN WATER WORKS ASSOCIATION - AWWA; WATER ENVIRONMENT FEDERATION - WEF. Standard methods for the examination of water and wastewater. 21th ed. Washington DC, 2005.

ARANDA, K. R.; FAGUNDES-NETO, U.; SCALETSKY, I. C. A. Evaluation of multiplex PCRs for diagnosis of infection with diarrheagenic Escherichia coli and Shigella spp. Journal of Clinical Microbiology, Washington DC, v. 42, n. 12, p. 5849-5853, 2004. http://dx.doi.org/10.1128/JCM.42.12.5849-5853.2004

BEGUM, Y. A.; TALUKDER, K. A.; NAIR, G. B.; SVENNERHOLM, A. M.; SACK, R. B.; QADRI, F. Enterotoxigenic Escherichia coli isolated from surface water in urban and rural Bangladesh. Journal of Clinical Microbiology, Washington DC, v. 43, n. 7, p. 3582-3583, 2005. http://dx.doi.org/10.1128/JCM.43.7.3582-3583.2005

BERN, C.; MARTINES, J.; DE ZOYSA, I.; GLASS, R. I. The magnitude of the global problem of diarrhoeal disease: a ten-year update. Bull WHO, Geneva, v. 70, n. 6, p. 705-714, 1992.

BHANUMATHI, R.; SABEENA, F.; ISAC, S. R.; SHUKLA, B. N.; SINGH, D. V. Molecular characterization of Vibrio cholerae O139 Bengal isolated from water and the aquatic plant Eichhornia crassipes in the river Ganga, Varanasi, India. Applied and Environmental Microbiology, Washington DC, v. 69, n. 4, p. 2389-2394, 2003. http://dx.doi.org/10.1128/AEM.69.4.2389-2394.2003 
BRANDL, M. T. Plant lesions promote the rapid multiplication of Escherichia coli O157:H7 on postharvest lettuce. Applied and Environmental Microbiology, Washington DC, v. 74, n. 17, p. 5285-5289, 2008. http://dx.doi.org/10.1128/AEM.01073-08

BRASIL. Conselho Nacional do Meio Ambiente - CONAMA. Resolução n ${ }^{\circ} 274$ de 29 de novembro de 2000. Disponível em: <http://www.mma.gov.br/port/conama/res/res00/ res27400.html>. Acesso em: 02 de setembro de 2011.

CARDONHA, A. M. S.; VIEIRA, R. H. S. F.; RODRIGUES, D. P.; MACRAE, A.; PEIRANO, G.; TEOPHILO, G. N. D. Fecal pollution in water from storm sewers and adjacent seashores in Natal, Rio Grande do Norte, Brazil. International Microbiology, Barcelona, v. 7, n. 3, p. 213-218, 2004.

CHAO, K. K.; CHAO, C. C.; CHAO, W. L. Evaluation of Colilert-18 for detection of coliforms and Escherichia coli in subtropical freshwater. Applied and Environmental Microbiology, Washington DC, v. 70, n. 2, p. 1242-1244, 2004. http://dx.doi.org/10.1128/AEM.70.2.1242-1244.2004

CLINICAL AND LABORATORY STANDARDS INSTITUTE - CLSI. Performance standards for antimicrobial susceptibility testing. M 100-S 19. Villanova, 2009.

DONNENBERG, M. S. Enteropathogenic Escherichia coli. In: BLASER, M. J.; SMITH, P. D.; RAVDIN, J. I.; GREENBERG, H. B.; GUERRANT, R. L. (eds.). Infections of the gastrointestinal tract. New York: Raven Press, 1995. p. 709-726.

FALCÃO, D. P.; VALENTINI, S. R.; LEITE, C. Q. F. Pathogenic or potentially pathogenic bacteria as contaminants of fresh water from different sources in Araraquara, Brazil. Water Research, Delft, v. 27, n. 12, p. 1737-1741, 1993. http://dx.doi.org/10.1016/ 0043-1354(93)90111-T

FEI, W. K.; RADU, S.; CHEAH, Y. K.; BENJAMIN, P. G.; LING, C. M. W. V.; HON, S. F. et al. Antibiotic resistance, plasmid profile and RAPD-PCR analysis of enteropathogenic Escherichia coli (EPEC) clinical isolates Southeast Asia. Southeast Asian Journal of Tropical Medicine and Public Health, Bangkok, v. 34, n. 3, p. 620626, 2003.

GUNZBURG, S. T.; TORNIEPORTH, N. G.; RILEY, L. W. Identification of enteropathogenic Escherichia coli by PCR-based detection of the bundle-forming pilus gene. Journal of Clinical Microbiology, Washington DC, v. 33, n. 5, p.1375-1377, 1995.

HALLER, L.; AMEDEGNATO, E.; POTÉ, J.; WILDI, W. Influence of freshwater sediment characteristics on persistence of fecal indicator bacteria. Water, Air, \& Soil Pollution, Heidelberg, v. 203, n. 1/4, p.217-227, 2009. http://dx.doi.org/10.1007/s11270-0090005-0

HAMELIN, K.; BRUANT, G.; EL-SHAARAWI, A.; HILL, S.; EDGE, T. A.; BEKAL, S. et al. A virulence and antimicrobial resistance DNA microarray detects a high frequency of virulence genes in Escherichia coli isolates from Great Lakes recreational waters. Applied and Environmental Microbiology, Washington DC, v. 72, n. 6, p. 42004206, 2006. http://dx.doi.org/10.1128/AEM.00137-06 
HAMNER, S.; BROADAWAY, S. C.; MISHRA, V. B.; TRIPATHI, A.; MISHRA, R. K.; PULCINI, E. et al Isolation of potentially pathogenic Escherichia coli O157:H7 from the Ganges river. Applied and Environmental Microbiology, Washington DC, v. 73, n. 7, p. 2369-2372, 2007. http://dx.doi.org/10.1128/AEM.00141-07

HIGGINS, J. A.; BELT, K. T.; KARNS, J. S.; RUSSELL-ANELLI, J.; SHELTON, D. R. tirand $s t x$-positive Escherichia coli in stream waters in a metropolitan area. Applied and Environmental Microbiology, Washington DC, v. 71, n. 5, p. 2511- 2519, 2005. http://dx.doi.org/10.1128/AEM.71.5.2511-2519.2005

HU, J.; SHI, J.; CHANG, H.; LI, D.; YANG, M.; KAMAGATA, Y. Phenotyping and genotyping of antibiotic-resistant Escherichia coli isolated from a natural river basin. Environmental Science \& Technology, Washington DC, v. 42, n. 9, p. 3415-3420, 2008. http://dx.doi.org/10.1021/es7026746

HUANG, D. B.; MOHANTY, A.; DUPONT, H. L.; OKHUYSEN, P. C.; CHIANG, T. A review of an emerging enteric pathogen: enteroaggregative Escherichia coli. Journal of Medical Microbiology, Reading, v. 55, n. 10, p. 1303-1311, 2006. http://dx.doi.org/10.1099/jmm.0.46674-0

ISHII, S.; YAN, T.; SHIVELY, D. A.; BYAPPANAHALLI, M. N.; WHITMAN, R. L.; SADOWSKY, M. J. Cladophora (Chlorophyta) spp. harbor human bacterial pathogens in nearshore water of lake Michigan. Applied and Environmental Microbiology, Washington DC, v. 72, n. 7, p. 4545-4553, 2006. http://dx.doi.org/10.1128/ AEM.00131-06

KÄMPFER, P.; NIENHÜSER, A.; PACKROFF, G.; WERNICKE, F.; MEHLING, A.; NIXDORF, K. et al. Molecular identification of coliform bacteria isolated from drinking water reservoirs with traditional methods and the Colilert-18 system. International Journal of Hygiene and Environmental Health, Kusterdingen, v. 211, n. 3/4, p.374-384, 2008. http://dx.doi.org/10.1016/j.ijheh.2007.07.021

NASCIMENTO, A. M.; VAN DER SAND, S. T. O uso de PCR na deteç̧ão de Escherichia coli enterotoxigênica em amostras de água de esgoto. Acta Scientiae Veterinariae, Porto Alegre, v. 35, n. 2, p. 187-194, 2007.

OBI, C. L.; GREEN, E.; BESSONG, P. O.; VILLIERS, B.; HOOSEN, A. A.; IGUMBOR, E. O.; POTGIETER, N. Gene encoding virulence markers among Escherichia coli isolates from diarrhoeic stool samples and river sources in rural Venda communities of South Africa. Water SA, Gezina, v. 30, n. 1, p. 37-42, 2004.

OCHOA, T. J.; BARLETTA, F.; CONTRERAS, C.; MERCADO, E. New insights into the epidemiology of enteropathogenic Escherichia coli infection. Transactions of the Royal Society of Tropical Medicine and Hygiene, High Holborn, v. 102, n. 9, p.852856, 2008. http://dx.doi.org/10.1016/j.trstmh.2008.03.017

OZGUMUS, O. B.; CELIK-SEVIM, E.; ALPAY-KARAOGLU, S.; SANDALLI, C.; SEVIM, A. Molecular characterization of antibiotic resistant Escherichia coli strains isolated from tap and spring waters in a coastal region in Turkey. Journal of Microbiology, v. 45, n. 5, p.379-387, 2007. 
PATHAK, S. P.; GOPAL, K. Prevalence of bacterial contamination with antibiotic-resistant and enterotoxigenic fecal coliforms in treated drinking water. Journal of Toxicology and Environmental Health, Philadelphia, v. 71, n. 7, p. 427-433, 2008. http://dx.doi.org/10.1080/15287390701838796

PISCIOTTA, J. M.; RATH, D. F.; STANEK, P. A.; FLANERY, D. M.; HARWOOD, V. J. Marine bacteria cause false-positive results in the Colilert-18 Rapid Identification Test for Escherichia coli in Florida waters. Applied and Environmental Microbiology, Washington DC, v. 68, n. 2, p. 539-544, 2002. http://dx.doi.org/10.1128/ AEM.68.2.539-544.2002

QADRI, F.; SVENNERHOLM, A. M.; FARUQUE, A. S. G.; SACK, R. B. Enterotoxigenic Escherichia coli in developing countries: epidemiology, microbiology, clinical features, treatment, and prevention. Clinical Microbiology Reviews. Washington DC, v. 18, n. 3, p. 465-483, 2005. http://dx.doi.org/10.1128/CMR.18.3.465-483.2005

REID, S. D.; BETTING, D. J.; WHITTAM, T. S. Molecular detection and identification of intimin alleles in pathogenic Escherichia coli by multiplex PCR. Journal of Clinical Microbiology, Washington DC, v. 37, n. 8, p. 2719-2722, 1999.

SATO, M. I.; SANCHEZ, P. S.; MARTINS, M. T.; REIS, M. H.; TRABULSI, L. R. Isolation of enterotoxigenic Escherichia coli in water and sewage in São Paulo, Brazil. Revista de Microbiologia, São Paulo, v. 14, n. 4, p. 276-281, 1983.

SHEHABI, A. A.; ODEH, J. F.; FAYYAD, M. Characterization of antimicrobial resistance and class 1 integrons found in Escherichia coli isolates from human stools and drinking water sources in Jordan. Journal of Chemotherapy, Florence, v. 18, n. 5, p.468-472, 2006.

SINGH, G.; VAJPAYEE, P.; RAM, S.; SHANKER, R. Environmental Reservoirs for Enterotoxigenic Escherichia coli in South Asian Gangetic Riverine System. Environmental Science \& Technology, Washington DC, v. 44, n. 16, p. 6475-6480, 2010. http://dx.doi.org/10.1021/es1004208

TURNER, S. M.; SCOTT-TUCKER, A.; COOPER, L. M.; HENDERSON, I. R. Weapons of mass destruction: virulence factors of the global killer enterotoxigenic Escherichia coli. FEMS Microbiology Letters, Hoboken, v. 263, n. 1, p. 10-20, 2006. http://dx.doi.org/ 10.1111/j.1574-6968.2006.00401.x

VALENTINI, S.R.; GOMES, T.A.T.; FALCÃO, D.P. Lack of virulence factors in Escherichia coli strains of enteropathogenic serogroups isolated from water. Applied and Environmental Microbiology, Washington DC, v. 58, n. 1, p. 412-414, 1992.

VIDAL, R.; VIDAL, M.; LAGOS, R.; LEVINE, M.; PRADO, V. Multiplex PCR for diagnosis of enteric infections associated with diarrheagenic Escherichia coli. Journal of Clinical Microbiology, Washington DC, v. 42, n. 4, p. 1787-1789, 2004. http://dx.doi.org/10.1128/JCM.42.4.1787-1789.2004

VIDAL, M.; KRUGER, E.; DURÁN, C.; LAGOS, R.; LEVINE, M.; PRADO, V. et al. Single multiplex PCR assay to identify simultaneously the six categories of diarrheagenic Escherichia coli associated with enteric infections. Journal of Clinical Microbiology, Washington DC, v. 43, n. 10, p. 5362-5365, 2005. http://dx.doi.org/ 10.1128/JCM.43.10.5362-5365.2005 
OLIVEIRA, K.W.; GOMES, F. C. O.; BENKO, G.; PIMENTA, R. S.; MAGALHÃES, P.P.; MENDES, E. N.; MORAIS, P. B. Antimicrobial resistance profiles of diarrheagenic Escherichia coli strains isolated from bathing waters of the Lajeado reservoir in Tocantins, Brazil. Ambi-Agua, Taubaté, v. 7, n. 2, p. 30-41, 2012. (http://dx.doi.org/10.4136/ambi-agua.756)

WORLD HEALTH ORGANIZATION - WHO. The world health report: making a difference. Geneva, 1999. 